\title{
Treatment of Hepatitis C-Mediated Glomerular Disease
}

\author{
Ana Maria Sandria Usama Elewab John J. Poteruchac Fernando C. Fervenzad \\ a Division of Infectious Diseases, Hospital São Lucas da PUCRS, Porto Alegre, Brazil; b New Kasr Al-Aini Teaching \\ Hospital, Cairo University, Cairo, Egypt; Divisions of ${ }^{\mathrm{C}}$ Gastroenterology and Hepatology, and ${ }^{\mathrm{d}}$ Nephrology and \\ Hypertension, Mayo Clinic, Rochester, Minn., USA
}

\section{Key Words}

Hepatitis C virus $\cdot$ Cryoglobulinemia $\cdot$ Nephropathy Therapy

\begin{abstract}
Chronic kidney disease (CKD) is becoming a major public health issue worldwide, mainly due to the increasing prevalence of hypertension, diabetes and aging population. Chronic hepatitis $\mathrm{C}$ virus (HCV) infection commonly involves the kidneys, can be a cause of CKD, and significantly impacts morbidity and mortality in these patients. Prompt recognition and knowledge of how to best manage these patients are essential in order to have a successful renal outcome. Patients with HCV and kidney involvement can often be managed with a specific combination of antiviral drugs, immunosuppressants, plasmapheresis, and newer monoclonal antibodies. However, no large randomized controlled trials have been conducted in this patient population, optimal management of HCV-mediated kidney diseases is not well defined, and treatment itself can be associated with significant toxicity in patients with CKD. This article reviews the recent literature, discusses the limitations of current therapies, as well as toxicity associated with treatment, and suggests future areas for research.

Copyright $\odot 2011$ S. Karger AG, Basel
\end{abstract}

\section{Introduction}

Hepatitis $\mathrm{C}$ virus (HCV) infection is a major public health problem with an estimated number between 130 and 170 million people infected worldwide and accounts for over 1 million deaths as a result of cirrhosis and liver cancer [1-3]. Hepatitis $\mathrm{C}$ is a major cause of liver-related morbidity and the leading indication for liver transplantation in the USA. HCV is also increasingly recognized as an instigator of B-cell lymphoproliferative disorders such as mixed cryoglobulinemia, and certain types of non-Hodgkin lymphoma. Although in patients with HCV infection and liver disease, renal involvement may be mild or clinically silent [4], a recent study showed that patients with HCV and age $<70$ years have a twofold increase in risk for developing end-stage renal disease (ESRD) when compared with patients without HCV infection [5]. A number of patients with HCV can be also coinfected with hepatitis B virus (HBV) which may be linked to a worst prognosis [6, 7]. Similarly, up to a third of HIV-infected patients worldwide are also infected with HCV [8]. In patients with HIV who acquired the infection parenterally, HCV coinfection rates are even higher (>75\%) [9].

The lack of safe and effective drugs to treat HCV-infected patients with chronic kidney disease (CKD) is a major concern $[10,11]$. Unfortunately, there are no large-

\section{KARGER \\ Fax +4161306 1234 E-Mail karger@karger.ch} www.karger.com
Fernando C. Fervenza, MD, $\mathrm{PhD}$

Division of Nephrology and Hypertension

Mayo Clinic College of Medicine

200 First Street, SW, Rochester, MN 55901 (USA)

Tel. +1 507266 7083, E-Mail fervenza.fernando@ mayo.edu 
Table 1. Spectrum of kidney disease in HCV-infected patients [cf. $14,15,19-28]$

Membranoproliferative glomerulonephritis with or without cryoglobulin deposition

Membranous nephropathy

IgA nephropathy

Mesangial proliferative glomerulonephritis

Focal segmental glomerulosclerosis

Postinfectious glomerulonephritis

Thrombotic microangiopathy

Focal segmental and necrotizing glomerulonephritis

Fibrillary glomerulonephritis

Immunotactoid glomerulopathy

scale clinical trials in patients with $\mathrm{HCV}$-associated kidney disease, thus strong treatment recommendations cannot be made in this patient population. Some of these issues have been highlighted in recent reviews $[10,12,13]$.

\section{HCV and Glomerulopathies}

Kidney involvement due to $\mathrm{HCV}$ is most commonly associated with type II cryoglobulinemia (mixed cryoglobulinemia) $[14,15]$. This form of small- and mediumvessel systemic vasculitis is characterized by clonal expansion of rheumatoid factor-expressing $B$ cells in the liver, lymph nodes and peripheral circulation, leading to the production of cryoglobulins [16]. Cryoglobulins are cold-insoluble immune complexes containing $\operatorname{IgM\kappa }$ rheumatoid factor, polyclonal IgG, HCV RNA and complement. Deposition of cryoglobulins on the vascular endothelium of organs such as skin, nerves and kidneys can induce a vasculitis that clinically manifests as palpable purpura, arthritis, neuropathy or glomerulonephritis in $5-20 \%$ of patients infected with HCV [17]. Kidney involvement may occur in up to $60 \%$ of these patients and is characterized by proteinuria, microscopic hematuria and mild to moderate renal insufficiency $[14,18]$. In 5\% of cases, patients may present with oliguric acute renal failure [19]. The majority of patients develop hypertension, which is often associated with increased fluid retention, and can be severe and difficult to control. More than $90 \%$ of patients with type II cryoglobulinemia have antibodies against $\mathrm{HCV}$, and $<5 \%$ of cases are now classified as 'essential' mixed cryoglobulinemia. The clinical course is characterized by remissions and clinical exacerbations [20]. Interestingly, only a minority of patients $(\sim 15 \%)$ will develop ESRD [18]. The major causes of mortality in these patients are cardiovascular events, liver failure, infections, and malignancies [20].

In cases of cryoglobulinemic glomerulonephritis, renal biopsy most commonly shows a membranoproliferative glomerulonephritis (MPGN type I) pattern of injury [20]. On light microscopy, prominent glomerular hypercellularity may be present as a result of massive infiltration of glomerular capillaries with mononuclear and polymorphonuclear leukocytes. Lobular accentuation of the glomerular tuft, increased matrix and mesangial cell proliferation, capillary endothelial swelling, splitting of capillary basement membrane, intracapillary thrombi, and accumulation of eosinophilic material representing precipitated immune complexes or cryoglobulins as well as a necrotizing vasculitis, with fibrinoid necrosis of the small- and medium-sized vessels can also be present. Immunofluorescence usually demonstrates deposition of $\operatorname{IgM}, \operatorname{IgG}$, and C3 in the mesangium and capillary walls. On electron microscopy, subendothelial immune complexes are usually seen, and in some cases together with subepithelial and mesangial deposits, as well as granular, fibrillar or immunotactoid deposits suggestive of cryoglobulins [19, 21]. A non-cryoglobulinemic MPGN has also been described in patients with HCV infection [14, $15]$.

Interestingly, classical signs/symptoms of cryoglobulinemia such as palpable purpura, arthritis, or neuropathy, are present in only $50 \%$ of patients with HCV and a MPGN [15]. It is also important to recognize that as many as $30-40 \%$ of the patients with type II, or more rarely type III cryoglobulinemia, do not have detectable circulating cryoglobulins at presentation [15]. This may be due, in part, to technical issues. The blood needs to be kept at $37^{\circ} \mathrm{C}$ until it is processed, otherwise cryoglobulins will precipitate and test results may be reported as negative. Laboratory tests that would suggest the presence of a cryoglobulin are the presence of a positive rheumatoid factor together with low $\mathrm{C} 4$ complement levels in a patient with a MPGN on renal biopsy.

Besides MPGN, other forms of glomerular disease have been described in patients infected with HCV including IgA nephropathy, membranous nephropathy $(\mathrm{MN})$, postinfectious glomerulonephritis, thrombotic microangiopathies, focal and segmental glomerulosclerosis and fibrillary and immunotactoid glomerulonephritis [19-28] (table 1). In an autopsy series of 188 consecutive patients with HCV, Arase et al. [29] reported that a MPGN was present in $11 \%, \mathrm{MN}$ in $2 \%$, and a mesangial proliferative glomerulonephritis in $17 \%$, while $45 \%$ of the cases showed no evidence of glomerular involvement. Re- 
nal involvement by a glomerular disease was more common in the presence of cirrhosis (59.2\%) than in the absence of cirrhosis (32.3\%) [29]. Thus, although MPGN is the most common lesion in the context of cryoglobulinemia, other glomerular lesions may occur making a kidney biopsy essential in order to establish the correct histological diagnosis in HCV patients and evidence of kidney disease.

A similar spectrum of glomerular disease has been reported in patients with concurrent HCV and HIV infections [30-34]. Of note, patients with concurrent HCVHIV infection had similar clinical presentations, with the majority presenting with nephrotic syndrome and renal insufficiency [33]. HIV alone can also be a cause of cryoglobulinemia [35]. The fact that in these patients kidney involvement is manifested clinically in a way that is very similar to patients with HIV-associated nephropathy (HIVAN), and thus may not undergo a kidney biopsy, together with the fact that laboratory tests suggestive of a HCV-mediated glomerular disease may be normal or negative (e.g. complement, cryoglobulinemia) are some of the reasons why only a few cases of HCV-mediated glomerulopathies in patients with HIV have been reported [8]. An additional factor is related to age of the patients with $\mathrm{HCV}$ which tend to clinically manifest in the 5th or 6th decade of life, an age span not common in HIV patients prior to the availability of highly active antiretroviral therapy. Similar to patients with HIV [36], antineutrophil cytoplasmic antibodies (ANCA) are frequently found in the sera of patients infected with HCV [37-39]. In some cases, antigen targets other than proteinase-3 (PR3) or myeloperoxidase (MPO) have been identified (i.e. bactericidal/permeability increasing protein-BPI or cathepsin G) [38]. No correlation has been found between ANCA positivity and the presence of clinically active vasculitis in these patients [40] and only a paucity of cases of ANCA-associated vasculitis in patients with HCV have been reported $[41,42]$.

As discussed above, the majority of patients with type II cryoglobulinemia are infected with HCV and all persons with proteinuria and cryoglobulinemia should be screened for HCV RNA even in the absence of clinical and/or biochemical evidence of liver disease. This is particularly important in dialysis patients with liver disease who characteristically have lower ALT levels than nondialysis patients, despite histological evidence of liver involvement [43]. Similarly, HCV-infected patients should be tested periodically for proteinuria, hematuria, and estimated GFR (eGFR) to detect possible HCV-associated kidney disease. Practice guidelines for treatment of $\mathrm{HCV}$ infection in general have been recently published and the reader is referred to those guidelines for specific recommendations [44]. For detailed information regarding treatment of HCV-mediated kidney disease the reader is referred to recently published KDIGO clinical practice guidelines for the prevention, diagnosis, evaluation, and treatment of hepatitis C in chronic kidney disease [45].

\section{Treatment Protocols}

In making treatment recommendations in patients with HCV-mediated kidney disease the following need to be taken into account: (a) viral genotype (e.g. genotypes 2 and 3 have better sustained virological response (SVR) than genotype 1); (b) the severity of the CKD and the chronic liver disease; (c) the risks of the treatment itself; (d) whether or not hemodialysis is being contemplated, and (e) whether there are other comorbidities that may affect morbidity and mortality, such as cardiovascular disease [44]. In addition, interleukin-28B polymorphisms have been associated with treatment outcome in hepatitis $\mathrm{C}$ patients [46]. It should also be noted that the majority of studies in patients with $\mathrm{HCV}$-mediated kidney disease have been small and/or uncontrolled. Thus, there is insufficient evidence-based data on which to base strong recommendations.

Of relevance is the fact that both interferon (IFN)- $\alpha$ $[47,48]$ and ribavirin (RBV) $[49,50]$ are excreted by the kidney and their clearances are impaired in patients with kidney failure [51, 52]. Consequently, both drugs should have their doses adjusted according to the degree of kidney function [53]. RBV, in particular, should be used with caution in patients with GFR $<50 \mathrm{ml} / \mathrm{min}$ [54]. In a few studies, reduced doses of RBV have been used, together with both standard and pegylated IFN- $\alpha$ (peg-IFN- $\alpha$ ), in patients with low GFR [22]. But in this patient population these combinations are associated with significant side effects and need to be closely monitored. The major IFNrelated side effects are: influenza-like symptoms, hematologic abnormalities (neutropenia, thrombocytopenia), depression, anorexia, diarrhea, dermatitis, alopecia, and increased infection rate. The main side effect of RBV is hemolytic anemia related to the high concentration of the drug in red blood cells when kidney function is markedly reduced. RBV is not generally recommended in patients with impaired kidney function (creatinine clearance $<50 \mathrm{ml} / \mathrm{min} / 1.73 \mathrm{~m}^{2}$ ), although low doses have been used. If RBV is used in patients with CKD stages 3-5, close monitoring for worsening anemia is required, be- 
cause even low-dose regimens can be associated with significant toxicity $[44,45]$. In patients with $\mathrm{HCV}$, coinfection with HIV adds another layer to the complexity of therapy. Patients with HIV tend to show faster progression of the renal disease and may have greater resistance to IFN- $\alpha$ [33]. Drugs used to treat HIV (e.g. zidovudine) may cause severe anemia when combined with therapy against $\mathrm{HCV}$ infection, and the interaction of RBV with reverse transcriptase inhibitors (e.g. didanosine) may result in mitochondrial toxicity, pancreatitis, or lactic acidosis [8].

Conservative treatment based on controlling edema, blood pressure, and hyperlipidemia should be applied to all patients. Blood pressure control is important both as protection against the cardiovascular risk of hypertension, and to reduce proteinuria and slow the progression of the renal disease. In patients with CKD, recent KDIGO hypertension guidelines recommend target blood pressure $<130 / 80 \mathrm{~mm} \mathrm{Hg}$, and that goal should be even lower in patients with proteinuria, and aiming to reduce proteinuria-to-creatinine ratio to $<500-1,000$ $\mathrm{mg} / \mathrm{g}$ [55]. Angiotensin-converting enzymes inhibitors and/or angiotensin II receptor blockers are effective antihypertensive agents that can reduce proteinuria and slow progression of renal disease in both diabetic and non-diabetic chronic nephropathy patients [56], and for these reasons they are the preferred agents to treat hypertension in proteinuric renal diseases. Lipid abnormalities associated with proteinuria are likely important players in the high cardiovascular risk in patients with CKD and/ or proteinuria and also provide a target for treatment.

\section{Aim of Antiviral Therapy}

The aim of antiviral therapy in HCV-positive patients is to eliminate the virus and reduce the generation of HCV-related antibodies and immune complexes [10]. The term SVR is used for patients with HCV RNA clearance, defined as absence of viral RNA from serum by a sensitive PCR assay that persists for $>6$ months following completion/discontinuation of therapy. SVR amounts to a cure of $\mathrm{HCV}$ infection. In patients with normal kidney function this aim can be best achieved by the use of pegIFN- $\alpha_{2 \mathrm{a} / 2 \mathrm{~b}}$ in combination with RBV, which results in SVR rate of $45-50 \%$ in genotypes 1 and 4 , and $70-80 \%$ in genotypes 2 and 3 in $\mathrm{HCV}$ monoinfected patients. This represents the current standard of care for HCV infection, with or without cryoglobulinemia $[44,53]$. The protease inhibitors telaprevir and boceprevir have been extensively tested in combination with peg-IFN and $\mathrm{RBV}$ and should become available for use in the near future.

IFN therapy may occasionally result in clinically exacerbation of vasculitis, thus requiring close monitoring [44]. A recent meta-analysis of clinical trials of initial pegIFN monotherapy in patients with ESRD and HVC concluded that peg-IFN does not provide an added benefit in terms of SVR (33\%) and dropout rate (23\%) when compared to standard IFN monotherapy (SVR and dropout rate equaled 38 and $15 \%$, respectively) [57].

\section{Patients with HCV Infection and eGFR $>60 \mathrm{ml} / \mathrm{min}$}

Treatment regimens and their doses will vary with the severity of the kidney disease. No dose adjustment is needed for patients with GFR $>60 \mathrm{ml} / \mathrm{min}$ [45]. This recommendation is based on the results of three large randomized trials that were completed in IFN-naive patients with normal kidney function [58-60]. The efficacy and safety of combined IFN and RBV therapy is not affected in patients with a GFR $>50 \mathrm{ml} / \mathrm{min} / 1.73 \mathrm{~m}^{2}$. As such, the results reported in patients with normal kidney function treated with peg-IFN + RBV should apply to CKD stages 1 and 2.

\section{Patients with HCV Infection and eGFR $<60 \mathrm{ml} / \mathrm{min}$}

There is a paucity of information regarding treatment of HCV-infected patients with GFR $<60 \mathrm{ml} / \mathrm{min}$ but still not yet on dialysis (CKD stages 3-5) and treatment recommendations are based on expert opinion. The recommended doses for this group are peg-IFN- $\alpha_{2 b}, 1 \mu \mathrm{g} / \mathrm{kg}$ s.c. once weekly or peg-IFN- $\alpha_{2 \mathrm{a}}, 135 \mu \mathrm{g}$ s.c. once weekly, together with RBV, $200-800 \mathrm{mg} /$ day in two divided doses, starting with the low dose and increasing gradually as long as side effects remain minimal and are manageable (table 2). Patients need weekly monitoring of hemoglobin levels, and erythropoietin may be needed to control anemia [61].

\section{Patients with Cryoglobulinemia and Mild to Moderate Proteinuria}

Monotherapy with IFN- $\alpha$ has been used in cryoglobulinemic glomerulonephritis with complete clearance of HCV RNA and improved kidney function; however, recurrence of viremia and relapses of kidney disease were universally observed after IFN was discontinued [62, 63]. Subsequent studies with IFN- $\alpha$ monotherapy [63-66] have yielded mixed results. Misiani et al. [63] treated 20 patients with IFN- $\alpha_{2 \mathrm{a}}, 1.5$ million units (MU) for 1 week and $3 \mathrm{MU}$ for 23 weeks $3 \times$ weekly, and although serum 
Table 2. Treatment according to stages of CKD [modified from 31]

\begin{tabular}{ll}
\hline eGFR, $\mathrm{ml} / \mathrm{min}$ & Recommended treatment \\
\hline GFR $>60$ & A \\
GFR $30-59$ & B \\
GFR $15-29$ & B \\
GFR $<15$ & B \\
Dialysis & C
\end{tabular}

$\mathrm{A}=$ Routine combination therapy according to viral genotype. $\mathrm{B}=$ peg-IFN- $\alpha_{2 \mathrm{~b}}, 1 \mu \mathrm{g} / \mathrm{kg}$ s.c. once weekly, or peg-IFN- $\alpha_{2 \mathrm{a}}, 135 \mu \mathrm{g}$ s.c. once weekly + RBV, 200-800 mg/day in two divided doses starting with low dose and increasing gradually. $\mathrm{C}=$ Controversial: standard IFN- $\alpha\left(\right.$ IFN $-\alpha_{2 \mathrm{a}}$ or IFN $\left.-\alpha_{2 \mathrm{~b}}\right) 3 \mathrm{mU} 3 \times$ weekly, or peg-IFN- $\alpha_{2 b}, 1 \mu \mathrm{g} / \mathrm{kg} /$ week, or peg-IFN- $\alpha_{2 \mathrm{a}}, 135 \mu \mathrm{g} / \mathrm{kg} /$ week \pm $\mathrm{RBV}$ in markedly reduced daily dose.

eGFR = Estimated glomerular filtration rate $[\mathrm{eGFR}=(140-$ age) $\times 1.2$ (weight in $\mathrm{kg}) / \mathrm{serum} \mathrm{Cr}(\mu \mathrm{mol} / \mathrm{l}) \times(0.85$ if female $)]$. If actual weight is $>20 \%$ than ideal body weight (IBW) recommend dosing according to the formula: Dosing weight $=\mathrm{IBW}+$ 0.4 (actual weight - IBW $) ;$ IBW $($ male $)=50 \mathrm{~kg}+0.9 \mathrm{~kg} \times(\# \mathrm{~cm}$ $>150 \mathrm{~cm}) ;$ IBW $($ female $)=45.5+0.9 \mathrm{~kg} \times(\# \mathrm{~cm}>150 \mathrm{~cm})$. If using measure GFR (e.g. iothalamate or creatinine clearance) for medication dosing in an obese patient, then use the result in $\mathrm{ml} / \mathrm{min}$.

creatinine decreased, there was no difference in proteinuria compared with patients not treated with IFN. No data on SVR were reported. Treatment with IFN- $\alpha$ may exacerbate cryoglobulinemic vasculitis $[67,68]$. Thus, it is recommended that IFN- $\alpha$ should be started after the acute flare has been controlled with immunosuppressive agents [69].

Better outcomes have been achieved by combined use of IFN- $\alpha$ with RBV [61, 70-72] and peg-IFN with RBV $[69,73-76]$. Sabry et al. [72] treated 20 patients with IFN$\alpha$ for 3 months, and in case of no-response addition of RBV $15 \mathrm{mg} / \mathrm{kg}$ for 12 months. Proteinuria was markedly reduced while serum creatinine was unchanged. No data on either SVR or follow-up are available. Similarly, Bruchfeld et al. [61] treated 7 patients with IFN- $\alpha_{2 b} 3 \mathrm{MU}(\mathrm{n}=$ 4) or $1.5 \mathrm{MU}(\mathrm{n}=1) 3 \times$ weekly or peg-IFN- $\alpha_{2 \mathrm{~b}} 50 \mu \mathrm{g}$ once a week $(\mathrm{n}=2)+$ RBV 200-800 mg daily for 24 weeks to 15 months and showed SVR in $71.4 \%$ (5 patients). Proteinuria was markedly reduced, hematuria resolved in 6 of 7 patients and GFR improved in 3 patients and was stable in others. Results were stable at 24 months of follow-up.

More recently, Alric et al. [76] treated 18 patients with IFN- $\alpha(3 \mathrm{MU} 3 \times$ weekly, $\mathrm{n}=14)$ or peg-IFN- $\alpha_{2 \mathrm{~b}}(1.5 \mu \mathrm{g} /$ $\mathrm{kg}$ per week, $\mathrm{n}=4$ ) and RBV 600-1,000 mg/day for 6-24 months. SVR occurred in $66.7 \%$ of the patients. Only patients with SVR showed reduction of proteinuria. Serum creatinine was unchanged. In a recent meta-analysis of controlled clinical trials comparing the efficacy and safety of antiviral versus immunosuppressive therapy (corticosteroids alone or in combination with cyclophosphamide) in patients with $\mathrm{HCV}$-associated glomerulonephritis, proteinuria decreased more (odds ratio 3.86) after IFN therapy (3 MU $3 \times$ weekly for at least 6 months) [77]. However, both treatments failed to show a significant improvement in kidney function. Recently published KDIGO guidelines suggest that patients with moderate proteinuria and slowly progressive kidney disease can be treated with a 12-month course of standard IFN- $\alpha$ or peg-IFN- $\alpha_{2 a}$ with dose adjusted as described below plus RBV (not recommended for patients with a GFR $<50 \mathrm{ml}$ / $\mathrm{min} / 1.73 \mathrm{~m}^{2}$ ) with or without erythropoietin support depending on the level of hemoglobin [45].

Patients with HCV and non-cryoglobulinemic glomerulopathies (e.g. MN, IgA nephropathy) can be considered for therapy with the use of IFN- $\alpha$ monotherapy or combination treatment with peg-IFN- $\alpha+\mathrm{RBV}$, as outlined above, but evidence for such a suggestion is lacking.

\section{Patients with Cryoglobulinemia Vasculitis and Marked Proteinuria}

Patients with nephrotic-range proteinuria and/or rapidly progressive kidney failure or an acute flare of cryoglobulinemia should be considered candidates for additional therapy with either high-dose corticosteroids (e.g. methylprednisolone pulse $0.5-1 \mathrm{~g} /$ day for 3 days; prednisone $1-1.5 \mathrm{mg} / \mathrm{kg} /$ day $)+$ cyclophosphamide $(2 \mathrm{mg} / \mathrm{kg} /$ day for 2-4 months; dose adjusted to age and GFR) with or without plasma exchange ( 31 of plasma $3 \times$ weekly for 2-3 weeks), or rituximab $\left(375 \mathrm{mg} / \mathrm{m}^{2}\right.$ once a week for 4 weeks). Once control of the vasculitic syndrome has been achieved, attention should be focused on treating the HCV infection directly with antiviral therapy as outlined above [45].

These recommendations are based on observations that high-dose corticosteroids are helpful in treating patients with cryoglobulinemic vasculitis. However, systemic corticosteroids are not curative, have significant side effects, and may lead to increases in HCV viral levels [16]. Similarly, there is a paucity of data on the combined use of immunosuppressive drugs (steroids or cyclophosphamide) and plasmapheresis, aiming in removing the circulating cryoglobulins and suppressing antibody and cryoglobulin production, in the treatment of cryoglobulinemia vasculitis. Case reports suggest that it is safe, and 
may result in improvement in glomerulonephritis [7880]. On the other hand, Rock and Clark [81] recently reviewed all reports of the use of plasma exchange for the treatment of cryoglobulinemia that included at least $5 \mathrm{pa}$ tients, and were part of the Cochrane Central Register of Controlled Trials or had been published between January 1988 and June 2008. Eleven articles were included and a total of 156 patients studied. None of the studies had a clear report of the apheresis procedures or clearly defined quantitative outcomes. The authors concluded that although these studies weakly support the use of plasma exchange on the treatment of cryoglobulinemia, there are no data from randomized controlled trials with adequate size that have tested the effect of plasma exchange versus placebo or versus immunosuppressive therapy.

Rituximab is a chimeric monoclonal antibody against the CD20 antigen present on B cells and was approved by the FDA for the treatment of relapsed or refractory nonHodgkin's lymphoma and more recently for patients with rheumatoid arthritis. It has been increasingly used in patients with autoimmune diseases including $\mathrm{MN}$ and ANCA-associated vasculitis $[82,83]$. The rational for using rituximab in these patients comes from the fact that mixed cryoglobulinemia in patients with $\mathrm{HCV}$ infection is considered a B-cell lymphoproliferative disorder. Thus, depletion of the B-cell clones producing IgM rheumatoid factor will halt the production of cryoglobulins. A number of small and/or uncontrolled studies have shown that rituximab is effective in inducing a complete and partial response rate in approximately 60 and $20 \%$ of the cases, respectively [84-88].

Ahmed and Wong [86] reported on a series of 22 patients with HCV-related kidney disease who received 2-6 weekly doses of rituximab $\left(375 \mathrm{mg} / \mathrm{m}^{2}\right)$ and showed remarkable reduction in proteinuria and stabilization of kidney function in patients with cryoglobulinemic vasculitis. Similarly, Roccatello et al. [85] reported on 11 patients infected with HCV and symptomatic type II cryoglobulinemia (renal involvement, marrow clonal restriction, large necrotizing ulcers, and polyneuropathy) who were resistant or intolerant to conventional therapy, and who were treated with rituximab $\left(375 \mathrm{mg} / \mathrm{m}^{2} \times 4\right.$ with 2 additional doses 1 and 2 months later) and no additional immunosuppression. Proteinuria, hematuria, erythrocyte sedimentation rate, cryocrit, rheumatoid factor, and IgM decreased while serum $\mathrm{C} 4$ levels increased and $\mathrm{HCV}$ viral load remained stable during short- and mediumterm follow-up. Bone marrow abnormalities were found to reverse to normal. Constitutional symptoms disappeared or ameliorated. No acute or delayed side effects were seen. These observations have also been supported by a report from Saadoun et al. [89] in 16 patients with severe refractory HCV-related cryoglobulinemia vasculitis treated with rituximab in combination with peg-IFN$\alpha_{2 b}$ and RBV. This last study suggests that early clinical response to rituximab may be a predictor of efficacy.

In some patients, HCV viremia may increase modestly following rituximab therapy, while in others it may remain unchanged or decrease, and the overall treatment has been considered safe [87]. Symptoms usually reappear with reconstitution of peripheral B cells. Patient can be retreated with rituximab, but the long-term safety of multiple courses of rituximab in patients with HCV is unknown. Side effects in patients with HCV treated with rituximab have included mild infusion reactions, serum sickness, severe vasculitic flares, infections, retinal artery thrombosis, and development of cold agglutinins [88]. Rituximab can also induce a cryoglobulinemic vasculitis resulting in acute renal failure [90]. Pre- and posttreatment monitoring of the cryoglobulin level is advised in patients treated with rituximab. Not all patients respond to rituximab. This may be related to the fact that in some patients, B-cell clones may be weekly positive or even negative for the $\mathrm{CD} 20$ antigen, thus unable to undergo Bcell depletion.

\section{Limitations of Current Therapies}

Limitations include the following: (1) there is a paucity of studies available; most studies are retrospective analyses with small sample sizes; (2) most of the available evidence comes from studies of patients referred with significant proteinuria, hematuria, or reduced kidney function; (3) information in patients with earlier evidence of kidney disease is lacking, and (4) outcomes measurements varied among studies making comparisons difficult.

\section{Recommendations for Treatment}

(1) We recommend that patients with HCV infection and glomerulonephritis receive treatment with peg-IFN$\alpha$ and/or with RBV in a multidisciplinary approach according to standard clinical practice guidelines for $\mathrm{HCV}$ infection. Treatment decisions should be individualized based on the severity of the disease, the potential for serious side effects, the likelihood of treatment response, the presence of comorbid conditions, and the patient's readiness for treatment. 
(2) The optimal therapy for patients with chronic HCV infection is the combination of peg-IFN and RBV, although protease inhibitors will be available in the near future and will be added to peg-IFN and RBV for the treatment of patients with chronic hepatitis C.

(3) Patients with chronic HCV infection and eGFR $>60 \mathrm{ml} / \mathrm{min}$ can be treated with the same combination antiviral therapy as that used in patients without kidney disease.

(4) Patients with chronic HCV infection and severe kidney disease but not yet on dialysis can be treated with reduced doses of both peg-IFN- $\alpha_{2 \mathrm{a}}(135 \mu \mathrm{g} /$ week $)$ and peg-IFN- $\alpha_{2 b}(1 \mu \mathrm{g} / \mathrm{kg} /$ week $)$ and RBV (200-800 mg/day) with careful monitoring for adverse effects.

(5) Patients with cryoglobulinemia and mild to moderate proteinuria and slowly progressive kidney disease can be treated with either standard IFN- $\alpha$ or reduced doses of peg-IFN- $\alpha$ and RBV.

(6) Patients with HCV and cryoglobulinemia with marked proteinuria and evidence of progressive kidney disease and/or an acute flare of cryoglobulinemia can be treated with cyclophosphamide + corticosteroids, or cy- clophosphamide + corticosteroids and plasma exchange, or rituximab (not necessarily in this order) followed by IFN- $\alpha$-based treatment once the acute process has subsided.

(7) Large epidemiologic studies are needed to determine the prevalence and types of glomerular lesions in HCV-infected patients, as well as to further evaluate whether glomerulonephritides other than MPGN (e.g. IgA nephropathy) represent a true association or a coincidental association with HCV infection.

(8) Randomized controlled trials with adequate follow-up in well-defined populations are also needed to establish the most efficacious treatment for patients with HCV-mediated kidney diseases. In particular, studies with well-defined outcomes (e.g. changes in proteinuria, kidney function, etc.) are needed. (9) Randomized controlled trials are required to evaluate the efficacy and safety of antiviral therapy, immunosuppressive therapy, plasma exchange and rituximab in patients with HCVmediated kidney diseases. Information regarding minimal effective dose, retreatment, and viral load after repeated treatments is needed.

\section{References}

1 Williams R: Global challenges in liver disease. Hepatology 2006;44:521-526.

-2 Poynard T, Yuen MF, Ratziu V, Lai CL: Viral hepatitis C. Lancet 2003;362:2095-2100.

-3 Alter MJ: Epidemiology of hepatitis C virus infection. World J Gastroenterol 2007;13: 2436-2441.

-4 Radhakrishnan J, Uppot RN, Colvin RB: Case records of the Massachusetts General Hospital. Case 5-2010. A 51-year-old man with HIV infection, proteinuria, and edema. N Engl J Med 2010;362:636-646.

-5 Tsui JI, Vittinghoff E, Shlipak MG, et al: Association of hepatitis $\mathrm{C}$ seropositivity with increased risk for developing end-stage renal disease. Arch Intern Med 2007;167:12711276.

-6 Vento S, Garofano T, Renzini C, et al: Fulminant hepatitis associated with hepatitis A virus superinfection in patients with chronic hepatitis C. N Engl J Med 1998;338:286-290.

7 Tsai JF, Jeng JE, Ho MS, et al: Independent and additive effect modification of hepatitis $\mathrm{C}$ and $\mathrm{B}$ viruses infection on the development of chronic hepatitis. J Hepatol 1996;24: 271-276.

-8 Waldman M, Marshall V, Whitby D, Kopp JB: Viruses and kidney disease: beyond HIV. Semin Nephrol 2008;28:595-607.
9 Sulkowski MS, Mast EE, Seeff LB, Thomas DL: Hepatitis C virus infection as an opportunistic disease in persons infected with human immunodeficiency virus. Clin Infect Dis 2000;30(suppl 1):S77-S84.

10 Perico N, Cattaneo D, Bikbov B, Remuzzi G: Hepatitis $\mathrm{C}$ infection and chronic renal diseases. Clin J Am Soc Nephrol 2009;4:207220.

$\checkmark 11$ Molino C, Fabbian F, Cozzolino M, Longhini C: The management of viral hepatitis in CKD patients: an unresolved problem. Int J Artif Organs 2008;31:683-696.

12 Chacko EC, Surrun SK, Mubarack Sani TP, Pappachan JM: Chronic viral hepatitis and chronic kidney disease. Postgrad Med J 2010; 86:486-492.

13 Fabrizi F, Messa P, Basile C, Martin P: Hepatic disorders in chronic kidney disease. Nat Rev 2010;6:395-403.

14 Johnson RJ, Gretch DR, Yamabe H, et al: Membranoproliferative glomerulonephritis associated with hepatitis $\mathrm{C}$ virus infection. $\mathrm{N}$ Engl J Med 1993;328:465-470.

15 Johnson RJ, Willson R, Yamabe H, et al: Renal manifestations of hepatitis $\mathrm{C}$ virus infection. Kidney Int 1994;46:1255-1263.

16 Charles ED, Dustin LB: Hepatitis C virusinduced cryoglobulinemia. Kidney Int 2009; $76: 818-824$.
17 Sansonno D, Gesualdo L, Manno C, et al: Hepatitis $C$ virus-related proteins in kidney tissue from hepatitis $C$ virus-infected patients with cryoglobulinemic membranoproliferative glomerulonephritis. Hepatology $1997 ; 25: 1237-1244$.

18 Galossi A, Guarisco R, Bellis L, Puoti C: Extrahepatic manifestations of chronic $\mathrm{HCV}$ infection. J Gastrointest Liver Dis 2007;16: 65-73.

19 Meyers CM, Seeff LB, Stehman-Breen CO, Hoofnagle JH: Hepatitis C and renal disease: an update. Am J Kidney Dis 2003;42:631657.

20 Roccatello D, Fornasieri A, Giachino O, et al: Multicenter study on hepatitis $C$ virus-related cryoglobulinemic glomerulonephritis. Am J Kidney Dis 2007;49:69-82.

21 D'Amico G: Renal involvement in hepatitis C infection: cryoglobulinemic glomerulonephritis. Kidney Int 1998;54:650-671.

22 Markowitz GS, Cheng JT, Colvin RB, et al: Hepatitis $\mathrm{C}$ viral infection is associated with fibrillary glomerulonephritis and immunotactoid glomerulopathy. J Am Soc Nephrol 1998;9:2244-2252.

23 Sabry A, E-Agroudy A, Sheashaa H, et al: $\mathrm{HCV}$ associated glomerulopathy in Egyptian patients: clinicopathological analysis. Virology 2005;334:10-16. 
-24 Kamar N, Izopet J, Alric L, et al: Hepatitis C virus-related kidney disease: an overview. Clin Nephrol 2008;69:149-160.

-25 Berger J, Yaneva H, Nabarra B: Glomerular changes in patients with cirrhosis of the liver. Adv Nephrol Necker Hosp 1977;7:3-14.

-26 Crawford DH, Endre ZH, Axelsen RA, et al: Universal occurrence of glomerular abnormalities in patients receiving liver transplants. Am J Kidney Dis 1992;19:339-344.

-27 Alpers CE, Kowalewska J: Emerging paradigms in the renal pathology of viral diseases. Clin J Am Soc Nephrol 2007;2(suppl 1):S6-S12.

28 Stehman-Breen C, Alpers CE, Fleet WP, Johnson RJ: Focal segmental glomerular sclerosis among patients infected with hepatitis C virus. Nephron 1999;81:37-40.

29 Arase Y, Ikeda K, Murashima N, et al: Glomerulonephritis in autopsy cases with hepatitis C virus infection. Intern Med 1998;37: 836-840.

-30 Gopalani A, Ahuja TS: Prevalence of glomerulopathies in autopsies of patients infected with the hepatitis $\mathrm{C}$ virus. Am J Med Sci 2001;322:57-60.

-31 Wrone EM, Carey H, Reilly RF: Glomerular lesions in HIV-infected patients: a Yale University Department of Medicine Residency Peer-Teaching Conference. Yale J Biol Med 1997;70:161-173.

-32 Stokes MB, Chawla H, Brody RI, et al: Immune complex glomerulonephritis in patients coinfected with human immunodeficiency virus and hepatitis $\mathrm{C}$ virus. Am J Kidney Dis 1997;29:514-525.

33 Cheng JT, Anderson HL Jr, Markowitz GS, et al: Hepatitis $\mathrm{C}$ virus-associated glomerular disease in patients with human immunodeficiency virus coinfection. J Am Soc Nephrol 1999;10:1566-1574.

>34 Morales E, Alegre R, Herrero JC, et al: Hepatitis-C-virus-associated cryoglobulinaemic membranoproliferative glomerulonephritis in patients infected by HIV. Nephrol Dial Transplant 1997;12:1980-1984.

-35 Scotto G, Cibelli DC, Saracino A, et al: Cryoglobulinemia in subjects with HCV infection alone, HIV infection and HCV/HIV coinfec tion. J Infect 2006;52:294-299.

-36 Elewa U, Sandri AM, Rizza SA, Fervenza FC: Treatment of HIV-associated nephropathies. Nephron Clin Pract 2011;118:c346c354.

-37 Wu YY, Hsu TC, Chen TY, et al: Proteinase-3 and dihydrolipoamide dehydrogenase (E3) are major autoantigens in hepatitis $C$ virus infection. Clin Exp Immunol 2002;128:347352.

-38 Lamprecht P, Gutzeit O, Csernok E, et al: Prevalence of ANCA in mixed cryoglobulinemia and chronic hepatitis $\mathrm{C}$ virus infection. Clin Exp Rheumatol 2003;21:S89S94.
39 Bonaci-Nikolic B, Andrejevic S, Pavlovic M, et al: Prolonged infections associated with antineutrophil cytoplasmic antibodies specific to proteinase 3 and myeloperoxidase: diagnostic and therapeutic challenge. Clin Rheumatol 2010;29:893-904.

40 Cojocaru M, Cojocaru IM, Iacob SA: Prevalence of anti-neutrophil cytoplasmic antibodies in patients with chronic hepatitis $\mathrm{C}$ infection-associated mixed cryoglobulinemia. Rom J Intern Med 2006;44:427-431.

41 Asai O, Nakatani K, Yoshimoto S, et al: A case of MPO-ANCA-related microscopic polyangiitis with mixed cryoglobulinemia (in Japanese). Nippon Jinzo Gakkai Shi 2006; 48:377-384.

42 Arend SM, Hagen EC, Kroes AC, et al: Activation of chronic hepatitis $\mathrm{C}$ virus infection by cyclophosphamide in a patient with cANCA-positive vasculitis. Nephrol Dial Transplant 1995;10:884-887.

43 Contreras AM, Ruiz I, Polanco-Cruz G, et al: End-stage renal disease and hepatitis $\mathrm{C}$ infection: comparison of alanine aminotransferase levels and liver histology in patients with and without renal damage. Ann Hepatol 2007;6:48-54.

44 Ghany MG, Strader DB, Thomas DL, Seeff LB: Diagnosis, management, and treatment of hepatitis C: an update. Hepatology 2009; 49:1335-1374.

45 KDIGO clinical practice guidelines for the prevention, diagnosis, evaluation, and treatment of hepatitis $\mathrm{C}$ in chronic kidney disease. Kidney Int Suppl 2008:S69-S77.

46 Nguyen CM, Mendes M, Tsunoda S, Ma JD Interleukin-28B genotype testing to determine response to the combination of pegylated-interferon and ribavirin for the treatment of hepatitis $\mathrm{C}$ virus. PLoS Curr 2011;3:RRN1207.

47 Bino T, Madar Z, Gertler A, Rosenberg H: The kidney is the main site of interferon degradation. J Interferon Res 1982;2:301-308.

48 Bocci V, Pacini A, Muscettola M, Paulesu L, et al: Renal filtration, absorption and catabolism of human $\alpha$-interferon. J Interferon Res 1981;1:347-352.

49 Glue P: The clinical pharmacology of ribavirin. Semin Liver Dis 1999;19(suppl 1):17-24.

50 Kramer TH, Gaar GG, Ray CG, et al: Hemodialysis clearance of intravenously administered ribavirin. Antimicrob Agents Chemother 1990;34:489-490.

51 Rostaing L, Chatelut E, Payen JL, et al: Pharmacokinetics of $\alpha$-IFN-2b in chronic hepatitis $\mathrm{C}$ virus patients undergoing chronic hemodialysis or with normal renal function: clinical implications. J Am Soc Nephrol 1998;9:2344-2348.

52 Uchihara M, Izumi N, Sakai Y, et al: Interferon therapy for chronic hepatitis $\mathrm{C}$ in hemodialysis patients: increased serum levels of interferon. Nephron 1998;80:51-56.

-53 Dore MP, Fattovich G, Sepulveda AR, Realdi G: Cryoglobulinemia related to hepatitis C virus infection. Dig Dis Sci 2007;52:897-907.
54 Bruchfeld A, Lindahl K, Reichard O, et al: Pegylated interferon and ribavirin treatment for hepatitis $\mathrm{C}$ in haemodialysis patients. J Viral Hepat 2006;13:316-321.

$55 \mathrm{~K} / \mathrm{DOQI}$ clinical practice guidelines on hypertension and antihypertensive agents in chronic kidney disease. Am J Kidney Dis 2004;43:S1-S290.

56 Jafar TH, Stark PC, Schmid CH, et al: Progression of chronic kidney disease: the role of blood pressure control, proteinuria, and angiotensin-converting enzyme inhibition: a patient-level meta-analysis. Ann Intern Med 2003;139:244-252.

57 Fabrizi F, Dixit V, Messa P, Martin P: Pegylated interferon monotherapy of chronic hepatitis $\mathrm{C}$ in dialysis patients: meta-analysis of clinical trials. J Med Virol 2010;82:768775 .

58 Fried MW, Shiffman ML, Reddy KR, et al: Peginterferon alfa-2a plus ribavirin for chronic hepatitis $\mathrm{C}$ virus infection. N Engl J Med 2002;347:975-982.

59 Manns MP, McHutchison JG, Gordon SC, et al: Peginterferon alfa-2b plus ribavirin compared with interferon alfa- $2 b$ plus ribavirin for initial treatment of chronic hepatitis C: a randomised trial. Lancet 2001;358:958-965.

60 Hadziyannis SJ, Sette H Jr, Morgan TR, et al: Peginterferon- $\alpha_{2 a}$ and ribavirin combination therapy in chronic hepatitis C: a randomized study of treatment duration and ribavirin dose. Ann Intern Med 2004;140: 346-355.

61 Bruchfeld A, Lindahl K, Stahle L, et al: Interferon and ribavirin treatment in patients with hepatitis $\mathrm{C}$-associated renal disease and renal insufficiency. Nephrol Dial Transplant 2003; 18:1573-1580.

62 Johnson RJ, Gretch DR, Couser WG, et al: Hepatitis $\mathrm{C}$ virus-associated glomerulonephritis. Effect of $\alpha$-interferon therapy. Kidney Int 1994;46:1700-1704.

63 Misiani R, Bellavita P, Fenili D, et al: Interferon alfa-2a therapy in cryoglobulinemia associated with hepatitis $\mathrm{C}$ virus. $\mathrm{N}$ Engl J Med 1994;330:751-756.

64 Cresta P, Musset L, Cacoub P, et al: Response to interferon- $\alpha$ treatment and disappearance of cryoglobulinaemia in patients infected by hepatitis C virus. Gut 1999;45:122-128.

65 Mazzaro C, Panarello G, Carniello S, et al: Interferon versus steroids in patients with hepatitis $\mathrm{C}$ virus-associated cryoglobulinaemic glomerulonephritis. Dig Liver Dis 2000; 32:708-715.

66 Komatsuda A, Imai H, Wakui H, et al: Clinicopathological analysis and therapy in hepatitis C virus-associated nephropathy. Intern Med 1996;35:529-533.

-67 Cid MC, Hernandez-Rodriguez J, Robert J, et al: Interferon- $\alpha$ may exacerbate cryoglobulinemia-related ischemic manifestations: an adverse effect potentially related to its anti-angiogenic activity. Arthritis Rheum 1999;42:1051-1055. 
68 Suzuki T, Yonemura K, Miyaji T, et al: Progressive renal failure and blindness due to retinal hemorrhage after interferon therapy for hepatitis $\mathrm{C}$ virus-associated membranoproliferative glomerulonephritis. Intern Med 2001;40:708-712.

69 Garini G, Allegri L, Lannuzzella F, et al: HCV-related cryoglobulinemic glomerulonephritis: implications of antiviral and immunosuppressive therapies. Acta Biomed 2007;78:51-59.

70 Garini G, Allegri L, Carnevali L, et al: Interferon- $\alpha$ in combination with ribavirin as initial treatment for hepatitis $\mathrm{C}$ virus-associated cryoglobulinemic membranoproliferative glomerulonephritis. Am J Kidney Dis 2001;38:E35.

7 Rossi P, Bertani T, Baio P, et al: Hepatitis C virus-related cryoglobulinemic glomerulonephritis: long-term remission after antiviral therapy. Kidney Int 2003;63:2236-2241.

72 Sabry AA, Sobh MA, Sheaashaa HA, et al: Effect of combination therapy (ribavirin and interferon) in HCV-related glomerulopathy. Nephrol Dial Transplant 2002;17:19241930.

73 Cacoub P, Saadoun D, Limal N, et al: Pegylated interferon alfa-2b and ribavirin treatment in patients with hepatitis $C$ virus-related systemic vasculitis. Arthritis Rheum 2005;52: 911-915.

74 Mazzaro C, Zorat F, Caizzi M, et al: Treatment with peg-interferon alfa- $2 \mathrm{~b}$ and ribavirin of hepatitis $\mathrm{C}$ virus-associated mixed cryoglobulinemia: a pilot study. J Hepatol 2005;42:632-638.
75 Saadoun D, Resche-Rigon M, Thibault V, et al: Antiviral therapy for hepatitis $\mathrm{C}$ virusassociated mixed cryoglobulinemia vasculitis: a long-term follow-up study. Arthritis Rheum 2006;54:3696-3706.

-76 Alric L, Plaisier E, Thebault S, et al: Influence of antiviral therapy in hepatitis C virus-associated cryoglobulinemic MPGN. Am J Kidney Dis 2004;43:617-623.

$\checkmark 77$ Fabrizi F, Bruchfeld A, Mangano S, et al: Interferon therapy for $\mathrm{HCV}$-associated glomerulonephritis: meta-analysis of controlled trials. Int J Artif Organs 2007;30:212219.

78 Koziolek MJ, Scheel A, Bramlage C, et al: Effective treatment of hepatitis $\mathrm{C}$-associated immune-complex nephritis with cryoprecipitate apheresis and antiviral therapy. Clin Nephrol 2007;67:245-249.

79 Namba T, Shiba R, Yamamoto T, et al: Successful treatment of HCV-related cryoglobulinemic glomerulonephritis with double-filtration plasmapheresis and interferon combination therapy. Clin Exp Nephrol 2010;14: 372-376.

-80 Frankel AH, Singer DR, Winearls CG, et al: Type II essential mixed cryoglobulinaemia: presentation, treatment and outcome in 13 patients. Q J Med 1992;82:101-124.

-81 Rock MA, Clark WF: Plasma exchange for treating cryoglobulinemia: a descriptive analysis. Transfus Apher Sci 2010;42:247251.

-82 Fervenza FC, Abraham RS, Erickson SB, et al: Rituximab therapy in idiopathic membranous nephropathy: a 2-year study. Clin J Am Soc Nephrol 2010;5:2188-2198.
83 Fervenza FC: Rituximab in ANCA-associated vasculitis: fad or fact? Nephron Clin Pract 2010;118:c182-c188.

84 Cacoub P, Delluc A, Saadoun D, et al: AntiCD20 monoclonal antibody (rituximab) treatment for cryoglobulinemic vasculitis: where do we stand? Ann Rheum Dis 2008;67: 283-287.

$>85$ Roccatello D, Baldovino S, Rossi D, et al: Rituximab as a therapeutic tool in severe mixed cryoglobulinemia. Clin Rev Allergy Immunol 2008;34:111-117.

$>86$ Ahmed MS, Wong CF: Should rituximab be the rescue therapy for refractory mixed cryoglobulinemia associated with hepatitis C? J Nephrol 2007;20:350-356.

87 Sansonno D, De Re V, Lauletta G, et al: Monoclonal antibody treatment of mixed cryoglobulinemia resistant to interferon- $\alpha$ with an anti-CD20. Blood 2003;101:38183826

88 Wink F, Houtman PM, Jansen TL: Rituximab in cryoglobulinaemic vasculitis, evidence for its effectivity: a case report and review of literature. Clin Rheumatol 30:293300.

89 Saadoun D, Resche-Rigon M, Sene D, et al: Rituximab combined with Peg-interferonribavirin in refractory hepatitis $\mathrm{C}$ virus-associated cryoglobulinaemia vasculitis. Ann Rheum Dis 2008;67:1431-1436.

90 Shaikh A, Habermann TM, Fidler ME, et al: Acute renal failure secondary to severe type I cryoglobulinemia following rituximab therapy for Waldenström's macroglobulinemia. Clin Exp Nephrol 2008;12:292-295.

\title{
Editorial Comment
}

\author{
Rashad Barsoum, Cairo
}

Despite the described broad spectrum of HCV-associated renal disease, the kidney is, surprisingly, not a primary target of the virus. According to current knowledge, only the hepatocyte and the B lymphocyte possess the complete machinery for viral entry, composed of the tetraspanin receptor $\mathrm{CD} 81$ and the scavenger receptor $\mathrm{B} 1$, integrated with other unknown molecules. Like other Flaviviridae, HCV can loosely attach to many other cells by adhering to surface glycosaminoglycans and lectins, and may even be internalized by low-density lipoprotein and asialoglycoprotein receptors, yet its release as an active genome is dependent on the mentioned molecules.
An interesting exception is the ability of infected B lymphocytes to transmit the virus into other non-permissive cells that lack the entry machinery.

$\mathrm{HCV}$-associated renal disease is traditionally attributed to the immune response to the virus. The complex interaction of viral products with the immune system [see Barsoum R: Nephrol Dial Transplant 2007;22:18401848] eventually leads to downregulation of macrophages, dendritic, natural killer and cytotoxic cells. This explains the synergistic interaction with other viral infections as HIV, and the increased incidence of infection, particularly after organ transplantation. On the other 
hand, B cells, which form the main intrahepatic lymphocytic population in HCV disease, are persistently activated by viral antigens leading to massive outpouring of IgG and IgM immunoglobulins and subsequently the formation of immune complexes. Some patients maintain a polyclonal response for decades, while others exhibit progressive differentiation into a monoclonal pattern. There is evidence that CD5-positive (B1) differentiation is ultimately associated with lymphomas, while CD5-negative (B2) clonality is associated with the formation of rheumatoid factor and subsequently cryoglobulins. Little is known about the factors which determine such differentiation.

While immune complexes and cryoglobulins are the principal causes of renal disease as well as many associated extrarenal manifestations of HCV infection, several observations suggest that other mechanisms may be involved. A direct cytopathic effect has been blamed for the pathogenesis of HCV-associated interstitial nephritis, where viral replication was documented in the renal tubule cells. Mesangial expansion in HCV disease has been attributed to viral RNA-induced upregulation of Toll-like receptor 3, which leads to increased production of IL-6, IL-1ß, M-CSF, IL-8/CXCL8, RANTES/CCL5, MCP-1/ CCL2, and ICAM-I. Endothelial injury in patients with cryoglobulinemia, as well as those with posttransplant thrombotic microangiopathy, may be partly attributed to the direct effect of the viral proteins, in analogy with their apoptotic effect on the hepatic sinusoids and umbilical cord vein. A possible cytopathic effect of the virus on podocytes has been postulated to explain the occurrence of membranous nephropathy and focal and segmental glomerulosclerosis in some patients with HCV disease, particularly under immunosuppressive treatment.

So, while kidney involvement in $\mathrm{HCV}$ disease must be seen and managed as an immune response to the virus, there is still a significant gap in our knowledge about the potential role of direct cytopathic effects of the virus. Further research in this area may lead to considerable strategic changes in our understanding of the disease and its treatment targets. 